\title{
SPECIFIC ENERGY CONSUMPTION - THE COMPARISON OF BELT CONVEYORS
}

\section{Natalia SUCHORAB*}

Faculty of Geoengineering, Mining and Geology, Wrocław University of Science and Technology, Wybrzeże Stanisława Wyspiańskiego 27, 50-370 Wrocław, Poland

\begin{abstract}
Belt conveyors (BCs), because of their high efficiency, are widely used for bulk material handling in the mining industry. However, due to the high level of conveyors' energy consumption, the belt conveyor systems generate a large part of mining costs. Therefore, the current solutions mostly focus on implementing new management strategies, which find energy consumption as a key indicator in designing belt conveyor systems. Belt conveyor equipment selection, conveying systems, operation, applied mining technology are considered to be areas where improvement of belt conveyors' energy efficiency may be achieved. Moreover, they can be used to implement novel standards for $\mathrm{BC}$ equipment and the proposal of defining new quality standards and creating BCs' classification has been already outlined. The main idea of the paper is to compare the values of specific energy consumption (SEC) of BCs with regard to the inclination angle of a conveyor route which results from technological needs. The multiple regression is used to find a relationship between two basic independent variables - the volume of transported material and conveyor's inclination angle - and a dependent variable (SEC). The procedure enables to determine the value of SEC which is required for lifting the material. Presented results prove that the value of SEC required for lifting the material is crucial for the interpretation of the SEC value when it comes to energy efficiency comparison.
\end{abstract}

Keywords: belt conveyor, energy efficiency, specific energy consumption

\section{INTRODUCTION}

The mining industry requires an enormous amount of energy for the main operational activities such as extraction, material handling and processing. Globally the mining sector uses nearly $11 \%$ of total world energy usage (McLellan et al. 2012). The analy-

\footnotetext{
* Corresponding author: natalia.suchorab@pwr.edu.pl (N. Suchorab)
}

doi: $10.37190 / \mathrm{msc} 192619$ 
sis of (Statistics Poland, 2018) data show that energy consumption in the mining sector has a decreasing trend (Fig. 1). Nevertheless, it still constitutes around 5\% of total energy consumption in Poland. Nowadays, the industry has to pay attention to energy management because of changes in energy prices and energy management legislation (Regulation EU 2017/1369, 2017). The necessity of competitiveness in the mining industry forces to improve the energy efficiency of the whole process. Reduction of an overall energy consumption may be achieved by reducing belt conveyors' energy consumption because of their significant impact on energy usage (Lodewijks, Pang 2013).

Continuous belt conveyor (BC) transportation systems are widely used in the mining industry because of their high capacity, durability, reliability and operational safety. Moreover, the significant advances in the field of belt conveyors make them competitive with truck transportation. In accordance to (Schnathmann 2019) conveyors may be energy efficient and may require even $90 \%$ less primary energy than truck transportation (Sichuan project). Although BCs are an efficient mean of transport, they are considered to be the significant consumers of an electric energy in mines and improvement of their energy-efficiency is of great importance. Additionally, authors in (Król 2013; Bajda et al. 2018) presented that the material handling constitutes some $12-25 \%$ of manufacturing cost of mining while optimization of conveying systems may reduce the total operating costs up to $30 \%$ (Marasova et al. 2018).

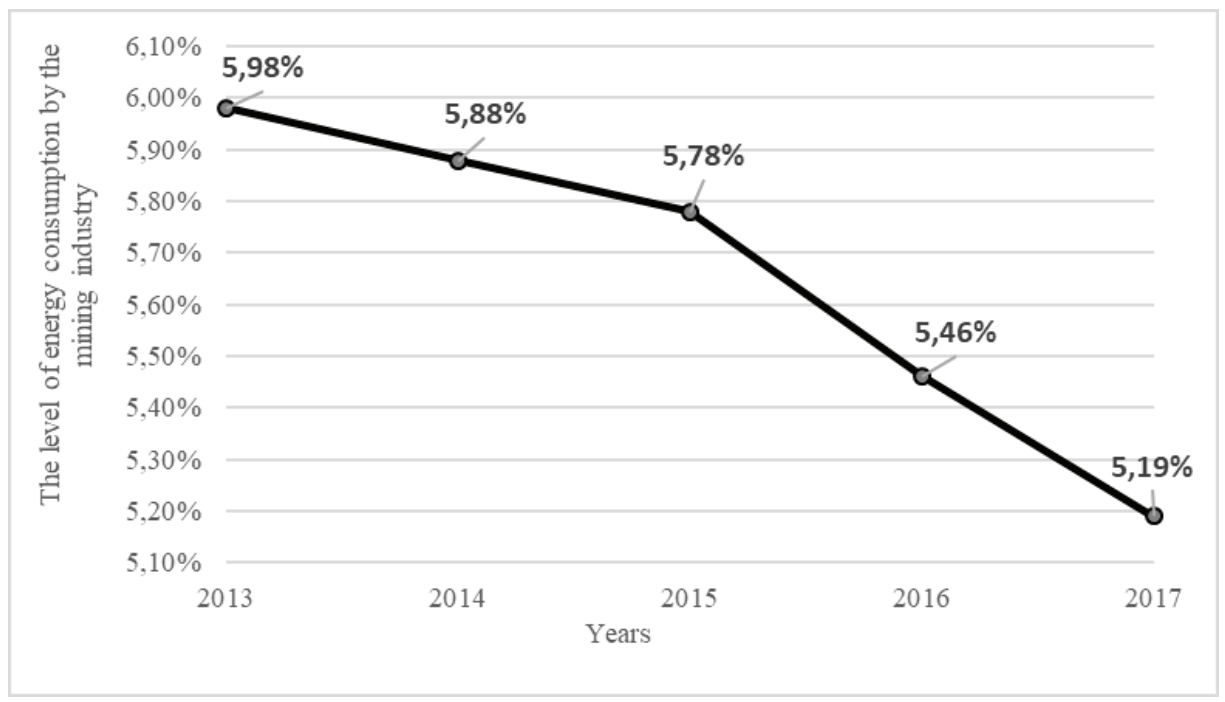

Fig. 1. Percentage of total energy consumption by the mining industry

Nowadays, the energy efficiency improvement seems to be a significant one because of reducing material handling energy costs. Due to this fact, there is a vast array of theoretical and practical researches in the conveyor's technology, which presents 
the problem from different perspectives. The energy efficiency is analyzed as a key indicator in designing and exploitation phase of conveyors - general definition of the problem and directions of development are presented in (Alspaugh 2004; Zhang, Xia 2011; Gładysiewicz et al. 2009; Kulinowski et al. 2013). Another point is that the majority of proposed solutions focuses on two levels: equipment and operational ones.

The equipment level concerns idlers, belt and drive system as a target of improving efficiency. The idlers rotational resistance, their durability, indentation rolling resistance of a belt and the efficiency of drive systems are crucial elements to consider when it comes to introducing highly efficient equipment or retrofitting the old one. The research in the field of idlers' technology and design influence idler rotational resistance were presented in (Król et al. 2017) and analysis of durability of bearings and idlers in (Król 2017). The optimized carrying idlers and energy efficient belt were implemented to the standard belt conveyor in the underground copper mine and tested in real condition. The results of experiment provided a significant reduction of the consumed energy (Kawalec et al. 2017). The system to measure variable idlers loads as a function of conveyor capacity was tested in lignite mine to obtain values of radial loads acting on the idlers and values of axial forces in the function of time for top idlers set (Gładysiewicz et al. 2019) which are crucial element in modernization and reducing energy consumption of the belt conveyor. In terms of belts in (Jansen 2008) the rubber compounds and structure of belts were indicated as a key thing to create energy optimized belts. In (Bajda, Hardygóra 2019; Gładysiewicz et al. 2017) it was proved that using energy-efficient belt instead of a standard one may yield a decrease of needed energy. Moreover, the new method of calculating identation rolling resistance which depends on belt's parameters and load value was developed and validated using experimental data (Gladysiewicz, Konieczna 2018). Last but not least is a drive system. The author in (Almeida et al. 2003) recommended to use energy-efficient motors and variable speed drives (VSD) to reduce energy losses. Also the conveyor system with VSD was mathematically modelled to create the management system for conveyors to minimize the energy consumption (Halepoto et al. 2016).

Another aspect of energy efficiency of belt conveyor is operational level. The main topics in this field are modeling the energy efficiency and optimal control of operation efficiency of belt conveyors. The new energy model for estimating usage of power in case of long conveyor belt has been proposed in (Mathaba, Xia 2015). The optimal switching control and the VSD based optimal control strategy was presented as strategies which implementation leads to energy and cost savings for long belt conveyors (Zhang, Xia 2010). In case of downhill conveyors authors in (Mathaba, Xia 2017) implemented optimal scheduling model to control conveyor belt systems to improve their energy efficiency. Moreover, cost optimal operation which leads to energy cost savings may be achieved using closed-loop Model Predictive Control approach (Luo et al. 2015). Another effective way to improve belt conveyors' energy efficiency is reducing their energy consumption by speed control. The application of speed control 
has been comprehensively studied in (He, 2017). The implementation of speed control principles for inclined belt conveyor enabled to reduce daily energy consumption by up to $12 \%$ (He et al. 2017). Additionally, authors went one step further presenting the methodology dedicated to keep healthy speed control in (He et al. 2018). In Polish conditions the problem has been considered within the influence of feed rate, conveyor's inclination angle and speed control on drives power demand (Karolewski 2017). It is widely known that coordination belt speed and feed rate may save the energy indeed and improve belt conveyors energy efficiency. However, to improve operational efficiency of belt conveyors the belt conveyor's energy model is needed. Building the proper energy models which are suitable for optimization purposes requires to be adjusted to operate conditions not to design ones. The optimization procedures implemented in conveying systems make environmental and financial benefits. However, sometimes reducing costs of electricity (for example via the time-of-use tariff) does not equal to energy consumption reducing. Therefore, the energy optimization of belt conveyors at operational level needs to keep the balance between technical and economic constraints (Zhang, Xia 2011).

\subsection{POET PERSPECTIVE AND CLASSIFICATION PERSPECTIVE}

Mentioned above equipment and operational levels are the part of POET point of view on energy efficiency improvement proposed in (He et al. 2018). The energy efficiency classification consists of four components: Performance efficiency (P), Operation efficiency $(\mathrm{O})$, Equipment efficiency (E), and Technology efficiency $(\mathrm{T})$ which are affected by technical and non-technical factors (Fig. 2a). Since combining these energy efficiency components together leads to sustainability, presented idea is specially dedicated to energy management activities. There are two ways to do so: forward and backward which enable to perform energy audit or energy system planning respectively. The POET Perspective covers and explains various elements and factors which influence energy efficiency.

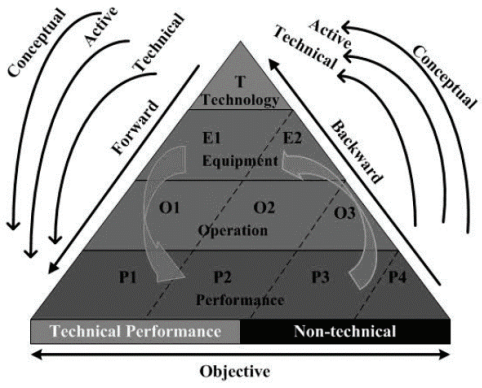

(a)

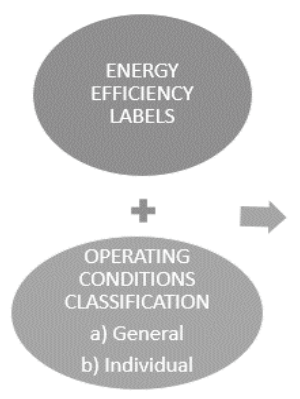

(b)

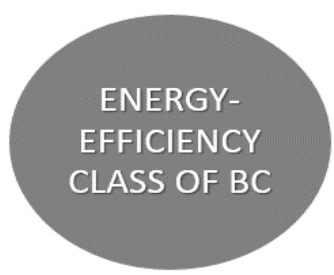

)

Fig. 2. Energy-efficiency perspectives: (a) POET Perspective (Xia, Zhang 2010), (b) Classification Perspective (Kawalec, Król 2019) 
Another approach which takes the energy consumption importance into account in conveyor transportation systems is classification of belt conveyors. Because of the growing awareness of the necessity of more efficient and eco-friendly belt conveyors systems, it was proposed to set new standards for belt conveyors' equipment which incorporates energy labelling (EEL) and operating conditions classes (OCC) (Kawalec, Król 2019). Energy efficiency labels are assumed to provide precise information about the parameters of $\mathrm{BC}$ components at least idlers, belts and drive. The operating conditions are suggested to be divided into two categories: general OCC of belt conveyors and individual OCC of a belt conveyors' components. The idea is reviewed in (Kawalec, Król 2019) in detail. The result of the approach is the BCs' component class or even BCs class (Fig. 2b) which may be a tool used to compare two different BCs and identify the possible ways of improvement the energy efficiency of a belt conveyor.

The presented perspectives correspond each other. The main advantage of these approaches is a holistic perspective on energy efficiency of belt conveyors.

\subsection{SPECIFIC ENERGY CONSUMPTION}

Considering the vast array of activities, which aim to improve efficiency of belt conveyor transport system, the accurate assessment of them is needed. The practical measure of such activities may occur the specific energy consumption (SEC) which shows the amount of energy which is needed to move $1 \mathrm{~kg}$ of bulk material for $1 \mathrm{~m}$ distance (Kulinowski et al. 2013).

SEC may be expressed as:

$$
S E C=\frac{N}{Q_{M} \cdot L}\left[\frac{\mathrm{W} \cdot \mathrm{s}}{\mathrm{kg} \cdot \mathrm{m}}\right],
$$

where $N$ is the required power of a drive system [W], $Q_{M}$ the mass flow of the handled material, $\left[\frac{\mathrm{kg}}{\mathrm{s}}\right]$, and $L$ is the length of the belt conveyor $[\mathrm{m}]$.

After transforming the equation (1) we can obtain:

$$
S E C=\frac{R T M}{\Sigma M \cdot \eta}\left[\frac{\mathrm{N}}{\mathrm{kg}}\right],
$$

where $R T M$ is resistance to motion $[\mathrm{N}], \Sigma M-$ the mass of handled material [kg], and $\eta$ is an efficiency of a drive system [-].

The relationships described by (1) and (2) indicate the possible directions of improving energy consumption of belt conveyor. The first one is reducing the RTM value, the second one is to increase loaded mass of conveyed material and the third one is to improve the efficiency of drive system. However, the problem of reducing 
energy consumption is more complicated because above parameters are strongly related.

The appropriate transformation of equation (2) enables to find in equation (3) the component of energy consumption for lifting the conveyed material.

$$
S E C=\frac{R_{M}+R_{S}}{M}+\frac{g}{\eta} \cdot \sin \delta\left[\frac{\mathrm{N}}{\mathrm{kg}}\right],
$$

where $R_{M}$ is the main resistance [N], $R_{S}$ is the special resistance [N], $M$ the mass of handled material $[\mathrm{kg}], g$ the standard gravity $\left[\frac{\mathrm{m}}{\mathrm{s}^{2}}\right]$, and $\delta$ conveyor's inclination angle $\left[^{\circ}\right]$.

In accordance to (3) the specific energy consumption is directly proportional to the sine of conveyor's inclination angle and inversely proportional to the conveyed mass of the material. Although the mass loading process can be managed, the conveyor's inclination angle relates to pursuing transportation task and represents technical constraint. As a result, the energy consumption may be reduced or increased by the conveyor's inclination angle. It seems that considering the SEC value as an only indicator to categorize random belt conveyors into low or high energy efficient group is not enough and the technical constraints should be taken into account at least.

\section{THE COMPARISON OF BELT CONVEYORS' ENERGY EFFICIENCY - CASE STUDY}

The aim of the presented case study is to assess the usefulness of specific energy consumption indicator for comparing belt conveyors' energy efficiency. The continuous belt conveyor system in lignite mine, on which the handled material stream is unchanging was analyzed. The system consists of 3 belt conveyors A, B and C which vary in conveyor's inclination angle (Table 1). Then, the analyzed conveyors can be named as uphill, horizontal and downhill ones respectively.

Table 1 . The values of conveyors' inclination angle $\left[{ }^{\circ}\right]$

\begin{tabular}{|c|c|}
\hline & Conveyor's inclination angle \\
\hline Conveyor A & 4,5 \\
\hline Conveyor B & 0 \\
\hline Conveyor C & $-0,5$ \\
\hline
\end{tabular}

The specific energy consumption values for 29 months period was determined using the automation system in the mine. Because the system enables to collect the data 
of the volume of conveyed material, the $\mathrm{Wh} / \mathrm{m}^{4}$ is a SEC value unit. The specific energy consumption values for analyzed belt conveyors are presented in Fig. 3 for which individual data values have been connected by line to present the rate of change between individual data points. The range of the highest SEC values between 0,9 and $1,8 \mathrm{Wh} / \mathrm{m}^{4}$ is observed for conveyor A, while for $\mathrm{B}$ and $\mathrm{C}$ conveyor it oscillates between 0,2 and $0,4 \mathrm{Wh} / \mathrm{m}^{4}$.

It is obvious that using downhill conveyor (conveyor $\mathrm{C}$ ) to transport a material from point A to point B is the most efficient. The problem of higher energy consumption by the slope conveyor is caused by the higher values of power needed to overcome gravity. As it is shown in (Alspaugh 2004; Kulinowski et al. 2013) lifting the material constitute the largest part of RTM and power consumption (e.g., $80 \%$ for $5^{\circ}$ conveyor's inclination angle).

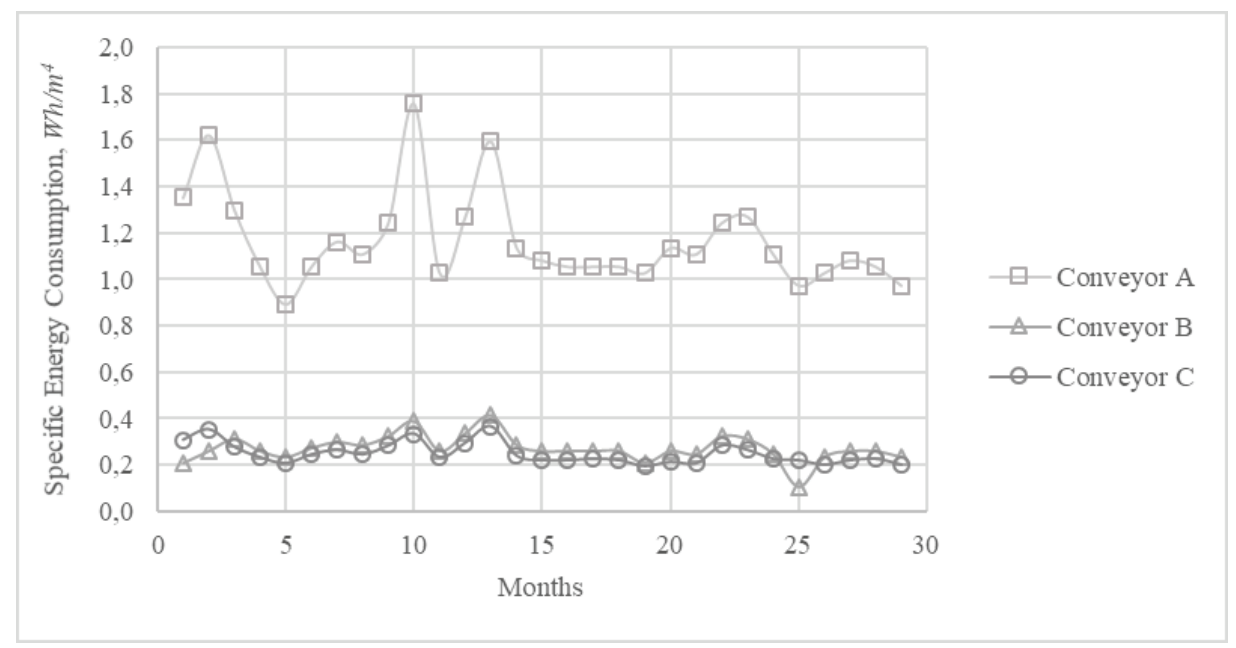

Fig. 3. The specific energy consumption values within 29 months period

As it is presented in Fig. 4, there is a relationship between SEC value and volume of conveyed material. The influence of the average daily volume capacity on the specific energy consumption and the level of installed power usage was presented in (Gładysiewicz, Migdał 2017). The regression lines of sampling points indicate the decrease in specific energy consumption with the transported volume of material increase. However, the little R square values suggest taking another predictor into consideration.

Because the volume of transported material is the same for three analyzed conveyors within a month the difference in SEC value is caused by conveyor's inclination angle. It means that after removing the component responsible for lifting the material, the range of SEC values should be similar for three analyzed belt conveyors. 


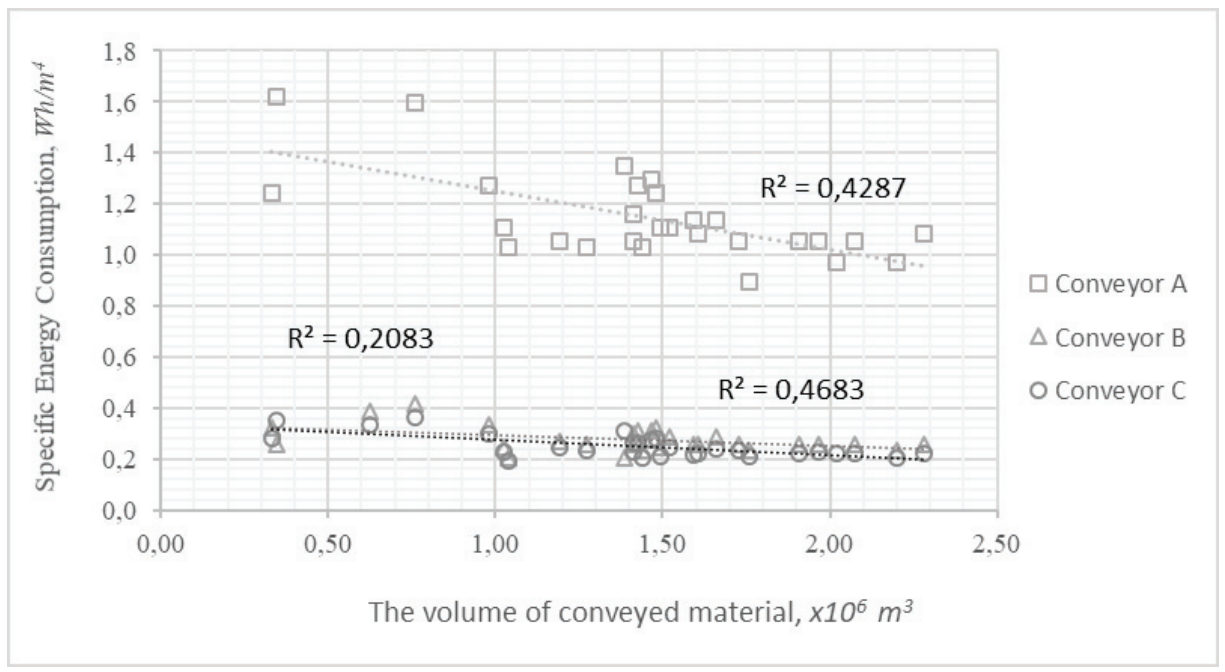

Fig. 4. The relationship between specific energy consumption value and volume of conveyed material

Taking into consideration Eq. (3), Figs. 3 and 4 and above assumption, it is supposed that two independent variables: the volume of transported material and sine of conveyor's inclination angle have a significant influence on dependent variable - SEC value used for comparing analyzed belt conveyors.

Therefore, the multiple linear regression dedicated for this set of data was run and the achieved formula for multiple linear regression is:

$$
y=-0.108 \cdot V+10.62 \cdot \sin \delta+0.465 .
$$

In general, as presented in Table 2 analyzed variables: $V$ and $\sin \delta$ statistically significantly predicted $S E C$ value $F(2,82)=839.749, p<0.0005, R 2=0.9534$. Considered variables added statistically significantly to the prediction $p<0,05$. The standard error of the estimate, which means the standard distance between the observations and the regression is $9.4 \%$. The standard error of the Volume of transported material coefficient is smaller than that of $\sin \delta$ and that of constant coefficient. Therefore, the model is able to estimate the coefficient for Volume of transported material with the greater precision.

Eventually, the analysis enabled to determine the part of SEC which describes the process of lifting the material in case of three considered conveyors. Due to subtraction this value from the primary SEC value, conveyors A and C may be treated as horizontal ones and they may be compared with conveyor B regarding their energy efficiency. As it is presented in Fig. 5 reduced values of SEC (the names of conveyors with apostrophes) indicate that the conveyor B is the most energy efficient one. 
Table 2. The output of Multiple Regression Analysis

\begin{tabular}{|c|c|c|c|c|c|c|}
\hline \multicolumn{7}{|c|}{ Model summary } \\
\hline \multicolumn{2}{|c|}{$R$} & $R$ square & \multicolumn{2}{|c|}{ Adjusted $R$ square } & \multicolumn{2}{|c|}{ Std. error of the estimate } \\
\hline 0.9764 & & 0.9534 & \multicolumn{2}{|l|}{0.9523} & \multicolumn{2}{|r|}{0.094} \\
\hline \multicolumn{7}{|c|}{ ANOVA } \\
\hline & Sum of squares & $d f$ & Mean square & \multicolumn{2}{|r|}{$F$} & Sig. \\
\hline Regression & 14.7988 & 2 & 7.3994 & \multicolumn{2}{|c|}{839.7488} & $2.4277 \cdot 10^{-55}$ \\
\hline Residuals & 0.7225 & 82 & 0.0088 & & & \\
\hline Total & 15.5213 & 84 & & & & \\
\hline \multicolumn{7}{|c|}{ Coefficients } \\
\hline & Coefficients & Std. error & $t$ & \multicolumn{2}{|c|}{ Sig. } & \\
\hline (Constant) & 0.465 & 0.032 & 14.4938 & \multicolumn{2}{|c|}{$2.481 \cdot 10^{-24}$} & \\
\hline $\sin \delta$ & 10.628 & 0.260 & 40.8167 & \multicolumn{2}{|c|}{$2.9925 \cdot 10^{-56}$} & \\
\hline$V$ & -0.108 & 0.021 & -5.1452 & \multicolumn{2}{|c|}{$1.7918 \cdot 10^{-6}$} & \\
\hline
\end{tabular}

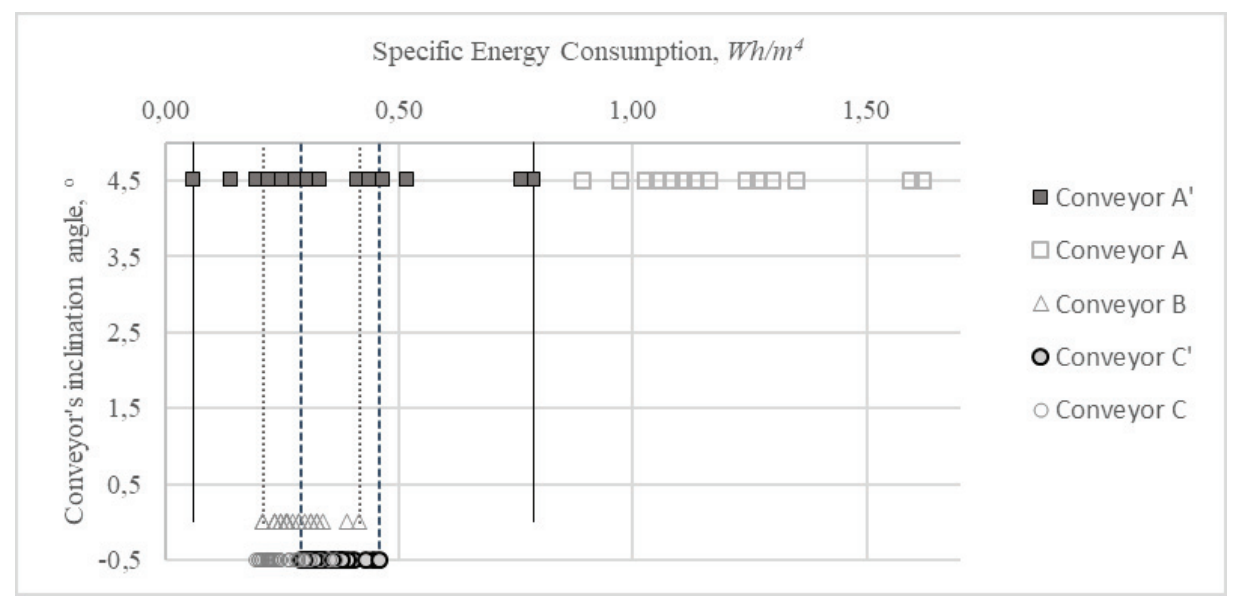

Fig. 5. The reduced specific energy consumption values

All in all, SEC value has been reduced by $75 \%$ on average for conveyor A and increased by $38 \%$ on average for conveyor C. However, even if the new SEC values are more similar than previously, there are seen differences in their ranges. Such results are probably connected with technology and operating conditions of the components of belt conveyors and belt conveyors system as well.

Because of that, the next step of analysis should be focused on analyzing worldwide data and defining the parameters which reflect energy consumption, operating conditions and technical constraints. It seems though that the assumptions presented in 
(Kawalec, Król 2019) as a new proposal of standardization belt conveyors perform as a guideline for a further work.

\section{CONLUSIONS}

Through the literature review, it can be concluded that the issue of energy efficiency of belt conveyors is of great importance. Current researches focus on improvements in field of energy efficient belt conveyors taking into account the necessity of sustainable development and implementing holistic perspective.

In this paper, it was shown that the specific energy consumption may be used as a general measure in analysis and assessment of energy efficiency of belt conveyors, however it needs to be used carefully. The belt conveyor system consisting of 3 belt conveyors with unchanged volume of material but with different conveyor's inclination angle was used in the assessment. The SEC values of belt conveyors were compared and then the multiple regression technique was proposed to obtain a relationship between SEC value and variables such as volume of transported material and conveyor's inclination angle. The analysis enabled to determine the value of SEC which is used for lifting the material. After subtraction this value, SEC indicators for analyzed belt conveyors achieved more similar ranges of values and indicating the most energy efficient belt conveyor was possible. However, some differences in values ranges appeared which mean that additional variables influence the SEC value.

Presented results prove that the value of SEC required for lifting the material is crucial for the interpretation of the SEC value when it comes to energy efficiency comparison. In addition to this, provided comparison of belt conveyors based on SEC values needs to take technological/transportation constraints and operating conditions into consideration.

\section{ACKNOWLEDGMENTS}

This article is financed from the statutory research grant No. 0401/0048/18 funded by the Ministry of Science and Higher Education.

\section{REFERENCES}

ALMEIDA De A.T., FONSECA P., BERTOLDI P., 2003, Energy-efficient motor systems in the industrial and in the services sectors in the European Union: characterisation, potentials, barriers and policies, Energy, Vol. 28, No. 7, 673-690.

ALSPAUGH M., 2004, Latest Developments in Belt Conveyor Technology, presented at MINExpo, Las Vegas, NV, USA, 2004.

BAJDA M., HARDYGÓRA M., 2019, Laboratory tests of operational durability and energy - efficiency of conveyor belts, IOP Conference Series: Earth and Environmental Science, Vol. 261, No. 1, 012002. 
BAJDA M., JURDZIAK L., KONIECZKA Z., 2018, Comparison of electricity consumption by belt conveyors in a brown coal mine. Part 1: Study of statistical significance of differences and correlations, Górnictwo Odkrywkowe, Vol. 59, No. 5, 4-14.

GŁADYSIEWICZ L., HARDYGÓRA M., KAWALEC W., 2009, Determing belt resistance, Bulk Handling Today, No. 5, 23-28.

GŁADYSIEWICZ L., KRÓL R., KISIELEWSKI W., KASZUBA D., 2017, Experimental determination of belt conveyors artificial friction coefficient, Acta Montanistica Slovaca, Vol. 22, No. 2, 206-214.

GŁADYSIEWICZ L., MIGDAŁ W., 2017, Specific energy consumption of belt conveyors, Transport Przemysłowy i Maszyny Robocze, No. 4, 5-9.

GŁADYSIEWICZ L., KONIECZNA M., 2018, Analytical method for establishing indentation rolling resistance, E3S Web of Conferences, Vol. 29.

GŁADYSIEWICZ L., KRÓL R., KISIELEWSKI W., 2019, Measurements of loads on belt conveyor idlers operated in real conditions, Measurement: Journal of the International Measurement Confederation, Vol. 134, 336-344.

HALEPOTO I.A., SHAIKH M.Z., CHOWDHRY B.S., UQAILI M.A., 2016, Design and Implementation of Intelligent Energy Efficient Conveyor System Model Based on Variable Speed Drive Control and Physical Modeling, International Journal of Control and Automation, Vol. 9, No. 6, 379-388.

HE D., 2017, Energy Saving for Belt Conveyors by Speed Control, Doctoral Thesis, Delft University of Technology.

HE D., PANG Y., LODEWIJKS G., 2017, Green operations of belt conveyors by means of speed control, Applied Energy, Vol. 188, 330-341.

HE D., PANG Y., LODEWIJKS G., LIU X., 2018, Healthy speed control of belt conveyors on conveying bulk materials, Powder Technology, Vol. 327, 408-419.

JANSEN M., 2008, The development of energy-optimized conveyor belts - A joint project of the Conveyor Belt Group of ContiTech $A C$ and RWE Power AG, World of Mining - Surface and Underground, 60 (2), 83-87.

KAROLEWSKI B., 2017, The influence of speed control on the power drawn by motors of the belt conveyor, Przegląd Elektrotechniczny, Vol. 1, No. 9, 76-79.

KAWALEC W., KROL R., GLADYSIEWICZ L., 2017, An Effective Belt Conveyor for Underground Ore Transportation Systems, IOP Conference Series: Earth and Environmental Science, Vol. 95, No. 4, 42047.

KAWALEC W., KRÓL R., 2019, Sustainable Development Oriented Belt Conveyors Quality Standards. [In:] Proceedings of the 14th International Scientific Conference: Computer Aided Engineering, ed. by E. Rusiński and D. Pietrusiak.

KRÓL R., 2013, Methods of Testing and Selection of the Belt Conveyor Equipment with Regard to Random Loading of a Transported Bulk Material, Wydział Geoinżynierii, Górnictwa i Geologii Politechniki Wrocławskiej, Wrocław.

KRÓL R., 2017, Studies of The Durability of Belt Conveyor Idlers with Working Loads Taken into Account, IOP Conference Series: Earth and Environmental Science, Vol. 95, No. 4, 42054.

KRÓL R., GLADYSIEWICZ L., KASZUBA D., KISIELEWSKI W., 2017, New Quality Standards of Testing Idlers for Highly Effective Belt Conveyors, IOP Conference Series: Earth and Environmental Science, Vol. 95, No. 4, 42055.

KULINOWSKI P., PANEK P., RUBACHA P., 2013, Aktualne kierunki poszukiwania energooszczędnych rozwiqzań w konstrukcji i eksploatacji przenośników taśmowych, Transport Przemysłowy i Maszyny Robocze, No. 3, 7-12.

LODEWIJKS G., PANG Y., 2013, Energy saving options for continuous transport systems, an exploration, presented at ICBMH 2013 - 11th International Conference on Bulk Materials Storage, Handling and Transportation. 
LUO J., HUANG W., ZHANG S., 2015, Energy cost optimal operation of belt conveyors using model predictive control methodology, Journal of Cleaner Production, Vol. 105, 196-205.

MARASOVA D., ANDREJIOVÁ M., GRINČOVÁ A., 2018, Continuous Conveyor System Evaluation Based On The Quality Of Conveyor Belts. International Multidisciplinary Scientific GeoConference Surveying Geology and Mining Ecology Management, SGEM, Vol. 18, No. 1.3, 197-205.

MATHABA T., XIA X., 2015, A Parametric Energy Model for Energy Management of Long Belt Conveyors, Energies, Vol. 8, No. 12, 13590-13608.

MATHABA T., XIA X., 2017, Optimal and energy efficient operation of conveyor belt systems with downhill conveyors, Energy Efficiency, Vol. 10, No. 2, 405-417.

MCLELLAN B.C., CORDER G.D., GIURCO D.P., ISHIHARA K.N., 2012, Renewable energy in the minerals industry: a review of global potential, Journal of Cleaner Production, Vol. 32, 32-44.

REGULATION (EU) 2017/1369 OF THE EUROPEAN PARLIAMENT AND OF THE COUNCIL of 4 July 2017 setting a framework for energy labelling and repealing Directive 2010/30/EU.

SCHNATHMANN R., 2019, A simple means of overcoming obstacles when transporting bulk materials, Georesources Journal, No. 01, 53-56.

Statistics Poland, 2018, Consumption of fuels and energy carriers. https://stat.gov.pl/obszary-tematyczne/ srodowisko-energia/energia/zuzycie-paliw-i-nosnikow-energii-w-2017-roku,6,12.html

XIA X., ZHANG J., 2010, Energy Efficiency and Control Systems - from a POET Perspective, IFAC Proceedings Volumes, Vol. 43, No. 1, 255-260.

ZHANG S., XIA X., 2010, Optimal control of operation efficiency of belt conveyor systems, Applied Energy, Vol. 87, No. 6, 1929-1937.

ZHANG S., XIA X., 2011, Modeling and energy efficiency optimization of belt conveyors, Applied Energy, Vol. 88, No. 9, 3061-3071. 